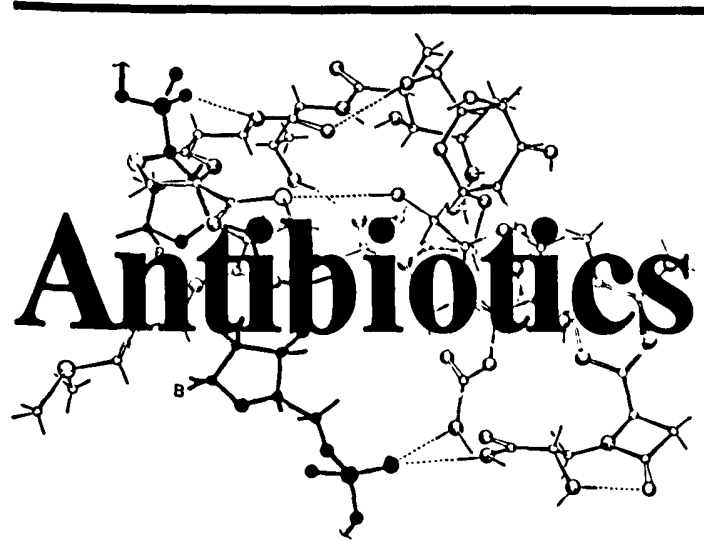

Volume I

\section{Mechanism of Action}

Editor: D. Gottlieb, P.D.Shaw

Out of print

Volume II

\section{Biosynthesis}

Editors: D. Gottlieb, P.D.Shaw

1967. 115 figures. XII, 466 pages

Cloth DM 168,-; approx. US \$ 72.50. ISBN 3-50-03725-X

Volume III

Mechanism of Action of Antimicrobial

\section{and Antitumor Agents}

Editors: J.W.Corcoran, F.E. Hahn

Assisted by J.E. Snell, K. L. Arom

1975. 193 figures. XII, 742 pages

Cloth DM 198,-; approx. US \$ 85.40. ISBN 3-540-06653-5

Volume IV

\section{Biosynthesis}

Editor: J.W. Corcoran

1981. 164 figures. XII, 380 pages

Cloth DM 198,-; approx. US \$ 85.40. ISBN 3-540-10186-1

“...This book can be recommended to all individuals involved in structural elucidation and synthesis of natural compounds, in the study and production of antibiotics and related bioactive compounds from biological or chemical backgrounds. It is the only arailable text on biosynthesis of the broad spectrum of antibiotic structures." FEBS Letters

"...The elucidation of the pathways that lead to the production of these antibiotics is a fascinating and important story that still has many new twists to it. This volume gives an excellent summary of the skill of Nature as a synthetic organic chemist."

Int.J. of Biochemistn

“..This latest volume on biosynthesis of antibiotics is part of a series of excellent books published on antibiotics.

This volume should be useful to research workers interested in antibiotics and the subject matter of their biosynthesis. It is particularly useful to students of the present and future..." Chemotherapy
Volume V (in 2 parts)

Part 1

Mechanism of Action of Antibacterial Agents

Editor: F.E.Hahn

1979. 80 figures, 38 tables. XII, 376 pages

Cloth DM 176,-; approx. US \$ 75.90. ISBN 3-540-09342-7

Part 2

Mechanism of Action of Antieukaryotic and Antiviral Compounds

Editor: F.E.Hahn

1979. 138 figures, 53 tables. XIII, 470 pages

Cloth DM 198,-; approx. US \$ 85.40. ISBN 3-540-09396-6

Special price for part 1 and 2 as a set:
Cloth DM 324,-; approx. US $\$ 139.70$
ISBN 3-540-09615-9

“... The well-chosen contributors are each outstanding authorities in their own fields in this rapidly growing area of research... The work contains a wealth of information, much of it recently acquired and elegantly organized. It gives the reader a clear view of the state of the art in this important field..." ASM New's

\section{Volume VI}

\section{Modes and Mechanisms of Microbial Growth Inhibitors

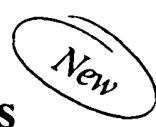

Editor: F.E.Hahn

1983. 127 figures. Approx. 370 pages

Cloth DM 268,-; approx. US \$ 115.50. ISBN 3-540-12169-2

Contents: Alafosfalin ( $\mathrm{R}_{0}$ 03-7008, Alaphosphin). - Arabinosylcytosine. - Chloramphenicol. - Emetine, Cryptopleurine, Tylocrebrine, and Other Functionally Related Alkaloids. Kirromycin and Related Antibiotics. - Anti- $\beta$-Lactamase Agents. - Mefloquine. - Metronidazole. - Neothramycin. Pyrazofurin. - Ribavirin. - Rubradirin. - Silver Sulfadiazine. - Sporamycin. - Streptothricin F. - Novel Inhibitors of Translation in Eukaryotic Systems. - Tunicamycin and Related Antibiotics. - Viral Translation Inhibitors. - Properties of Virginiamycin-like Antibiotics (Synergimycins), Inhibitors Containing Synergistic Components. - Subject Index.

The concluding volume in this series Antibiotics $\mathbf{V}$ presents extensive contributions on mechanisms or modes of action of antibiotics, drugs of higher plant origin, and synthetic chemotherapeutics. All articles are written by recognized experts from their own experimental studies. The format of the preceding volumes has been faithfully maintained. The study of Antibiotics VI will bring the professional reader upto-date on the molecular basis of action of clinical, agricultural, and theoretically interesting growth inhibitors.

\section{Springer-Verlag} Berlin Heidelberg New York Tokyo Tiergantenstr. 17, D-6900 Heidelberg I or 175 Finh Ave., New York, NY 10010, USA or 37.3, Ilongo 3-chome, Bunkyo-ku. Tohyo 113, Japan 


\section{Titles on preventive and social medicine currently available include:}

The Battle Against Bacteria: A Fresh Look P. BALDRY

The Battle

\section{Against Heart Disease}

P. BALDRY

\section{Bacterial}

Resistance and Susceptibility to Chemotherapeutic Agents

L. E. BRYAN

Hard covers 117.50 net Paperback $£ 7.95$ net

Natural History of Infectious

\section{Disease}

Fourth Edition

MACFARLANE BURNET

and D. O. WHITE

Hard covers $£ 23.50$ net Paperback $\mathbf{6 9 . 5 0}$ net
Manual for the Identification of Medical Bacteria

S. T. COWAN and K. J. STEEL

$£ 20.00$ net

Concept and Practice of Therapeutic Teams Edited by H. DE CLERCQ,

J. W. POSTON and JOAQUIN BONAL

Progress in

Clinical Pharmacy V

$£ 17.50$ net

Theory and Practice in Experimental Bacteriology Second Edition

G. G. MEYNELL and ELINOR MEYNELL $£ 27.50$ net

Social Contexts of Health, IIIness and Patient Care

Edited by ELLIOT G. MISHLER

Hard covers $\mathbf{} 22.50$ net Paperback f6.95 net

CAMBRIDGE UNIVERSITY PRESS 
Papers for publication should be sent to Professor J. R. Pattison, Department of Medical Microbiology, King's College Hospital Medical School, Denmark Hill, London SE5 8RX. The typescript and two copies should be sent with 3 copies of all tables and iilustrations. Papers forwarded to the Editor for publication are understood to be offered to the Journal of Hygiene alone, unless the contrary is stated.

\section{General}

Careful preparation of manuscripts will promote rapid publication. Authors are advised to refer to a recent issue of the journal in addition to the notes below, paying particular attention to the form of references, tables and figures and the use of symbols and abbreviations. Papers should be in double-spaced typescript throughout (including reference lists, footnotes and legends) on A4 paper with a left hand margin of at least $4 \mathrm{~cm}$.

\section{Format}

Papers must commence with a separate title page indicating the full title, initial(s), surname(s), address(es) of the authors and a short title not exceeding 45 characters. Papers should usually be divided into SUMMARY, INTRODUCTION, MATERIALS AND METHODS, RESULTS, DISCUSSION and REFERENCES. Some observations are best described in the form of a continuous narrative with the only subsection being a Summary at the beginning. Such papers will also be considered.

Acknowledgements are put at the end of the discussion after a space of one line.

\section{Tables}

Tables should be numbered separately with arabic numerals and each table typed on a separate sheet of paper. Whenever possible they should be so designed that they can be printed across the width of a page. Note that columns and lines are not separated by vertical or horizontal lines but are grouped by the use of braces of varying lengths.

\section{Illustrations}

Line drawings, diagrams and charts should be accurately drawn on plain white board or paper or faintly blue-lined graph paper and should not be more than twice publication size. Points should be indicated by the following symbols : $O, \triangle, \square, \boldsymbol{\varphi}, \boldsymbol{\Lambda}$. Lettering and numbering will not be directly reproduced but should be clearly shown either in pencil on the drawing or on overlaid transparent paper.

Illustrations for plates should be sent as unmounted glossy prints with good contrast. If more than one photograph is to be included in a single plate, a rough sketch of the suggested lay-out should be sent.

Legends for figures and descriptions of plates should be typed on separate sheets of paper. Each illustration should bear on the back the author's name and illustration number.

\section{References}

In the text references by up to three authors are cited in the form Jones, Smith \& Brown (1950) and those by four or more authors in the form Jones et al. (1950).

The reference list should be arranged alphabetically and should include authors' names, initials, year of publication in parentheses, title of the paper, name of the journal in full, the volume number and first and last page numbers. References to books and monographs should be in the form: authors' names, initials, year of publication in parentheses, title, edition editors (if appropriate), page number(s), place of publication and publisher. 


\section{Contents}

Edtoria: Noble, W. C. The new hospital epidemiology

Naidoo, JAY, Noble, W. C., WeisgmanN, A. and DYke, K. G. H. Gentamicin-resistant staphylococci: genetics of an outbreak in a dermatology department

Cohen, D. R., Porté, I. A., Rerd, T, M. S., Sharp, J. C. M., Forbes, G. I. and P'itersoir, G. M. A cost benefit study of milk-borne salmonellosis . .

HARvEY, R. W. S. and $\dot{P}_{R} \mathrm{ICH}_{\mathrm{F}}$ T. H. Salmonella isolation from reptilian faeces: A discussion of appropriate cultural techniques

Hinton, M., Arr, E. A., Allen, Vivien and Linton, A. H. The excretion of Salmonella typhimurium in the faeces of calves fed milk substitute.

FENLON, D. R. A comparison of salmonella serotypes found in the faeces of gulls feeding at a sewage works with serotypes present in the sewage

Fricker, C. R., Girdwood, R. W. A. and Munro, D. A ccmparison of enrichment media for the isolation of salmonellae from seagull cloacal swabs

OOSTEROM, J. and NOTERMANS, S. Further research into the possibility of salmonella-free fattening and slaughter of pigs

SKJOLD, S. A., WANNAMAKER, L. W., JOHNGON, D. R. and MARgolis, H. S. Type 49 Sireptococcus pyogenes: Phage subtypes as epidemiological markers in isolates from skin sepsis and acute glomerulonephritis

OLuSANYA, O., AdeBayo, J. O. and Williams, Bolance. Campylobacter jejuni as a bacterial cause of diarrhoea in Ile-Ife, Nigeria .

Ashoroft, J. and Pomerox, N. P. The generation of aerosols by accidents which may occur during plant-scale production of micro-organisms

Dadi, A. H., Stewart, Celia M. and Town, Margaret M. A standardized monitor for the control of ethylene oxide sterilization cycles

Uмон, J. U., Adestyun, A. A., Adekeye, J. O. and NAdarajah, M. Epidemiological features of an outbreak of gastroenteritis/cholera in Katsina, Northern Nigeria

Cohen, B. J., Mortimer, P. P. and Pereira, M. S. Diagnostic assays with monoclonal antibodies for the human serum parvovirus-like virus (SPLV)

Naikhin, A. N., Tsaritgina, I. M., Oleinikova, E. V., Syrodorva, L. G., Korcha nova, N. L., Denisov, G. M. and Shrartsman, Ya. S. The importance of antineuraminidase antibodies in resistance to influenza $A$ and immunologic memory for their synthesis.

MURPhY, A. M., GrommanN, G. S. and Sexton, M. F. H. Infectious gastro. enteritis in Norfolk Island and recovery of viruses from drinking water.

GRILLI, E. A. and S m r T, A. J. The use of a radial haemolysis test for neuraminidase antibodies in the diagnosis of influenza $\mathbf{A}$ infection . . . .

Mancini, G., Donatelir, I., Arangro-Rurz, G., Rozera, C. and Macchia, T. Comparison of haemagglutination-inhibition and single radial haemolysis techniques for detecting antibodies to influenza $A$ and $B$ viruses

Ohara, H., Naruto, H., WAtanabe, W. and EBisawa, I. An outbreak of hepatitis A caused by consumption of raw oysters

\section{CAMBRIDGE UNIVERSITY PRESS}

The Pitt Building, Trumpington Street, Cambridge CB2 1RP

32 East 57th Street, New York, 10022 